\title{
GOODS IN TRANSIT AND INTELLECTUAL Property under the EU law and Case- LAW OF THE COURT OF JUSTICE
}

\author{
Radim Charvát ${ }^{1}$
}

\section{Faculty of Law, Masaryk University, Czech Republic email: charvat@law.muni.cz}

CHARVÁT, Radim. Goods in Transit and Intellectual Property under the EU law and Case-law of the Court of Justice. International and Comparative Law Review, 2014, Vol. 14, No. 2, pp. 93-104. DOI: 10.1515/iclr-2016-0054.

\begin{abstract}
The paper addresses the issue whether customs authorities of Member States are entitled to suspend or detain goods in transit (i.e., products directing from one nonMember State to another non-Member State through the EU) and the evolving case-law of the Court of Justice related to this matter.

Prior to the judgment in Philips and Nokia cases, a so-called manufacturing fiction theory was applied by some Member State courts (especially Dutch courts). According to this theory, goods suspended or detained by customs authorities within the EU were considered to be manufactured in the Member State where the custom action took place. In the Philips and Nokia judgments, the Court of Justice rejected this manufacturing fiction theory.

But the proposal for amendment to the Regulation on Community trade mark and the proposal of the new Trademark directive, as a part of the trademark reform within the EU, go directly against the ruling in the Philips and Nokia cases and against the Understanding between the EU and India.
\end{abstract}

Keywords: goods in transit, goods infringing intellectual property rights, manufacturing fiction theory, customs action

\section{Introduction}

Until the end of 2013, Council Regulation (EC) No 1383/2003 of 22 July 2003 concerning customs action against goods suspected of infringing certain intellectual property rights and the measures to be taken against goods found to have infringed such rights was in force (hereinafter "Regulation No 1383/2003"). This regulation repealed Council Regulation (EC) No 3295/94 of 22 December 1994 laying down measures concerning the entry into the Community and the export

1 Department of International and European Law, Faculty of Law, Masaryk University, Czech Republic 
and re-export from the Community of goods infringing certain intellectual property (hereinafter "Regulation No 3295/94"). The aim of both regulations was to combat goods infringing intellectual property rights entering the $\mathrm{EU}$ from third countries. However, a question whether or not these regulations are applicable to goods in transit (i.e. to products directing from one non-Member State to another non-Member State through the European Union) arose. In other words, whether customs authorities of Member States are entitled to suspend or detain such goods in transit infringing intellectual property rights in the EU. This paper will address this issue and the evolving case-law of the Court of Justice (hereinafter "the CJ") related to this matter.

\section{Case-law of the Court of Justice}

\section{Case-law prior to Philips and Nokia Cases}

Article 1(1) of Regulation No 1383/2003 as well as the Regulation No. 3295/94 was interpreted from the beginning that customs authorities are entitled to suspend or detain release of goods suspected of infringing an intellectual property right regardless of whether the products are placed under a suspensive procedure ((inter alia, external transit and customs warehousing)) or in transshipment through the EU customs territory. This opinion was supported by previous case-law of the $\mathrm{CJ}$.

In its judgment of April 6, 2000, the CJ made clear that Article 1 of Regulation 3295/94 having a similar nature applies to goods in transit. ${ }^{2}$ In that case, Austrian customs detained T-shirts in external transit suspected of being counterfeits of the plaintiff's (Polo/Lauren Company's from the USA) trademarks. Thus, the consignor of the goods was the defendant who had its registered office in Indonesia and the consignee of the goods was a Polish company. The goods were directed from Indonesia to Poland, which was not of an EU Member State at that time. The CJ did not agree with the German government and held that the Regulation in question applied to goods passing through the EU territory from a non-EU member country destined for another non-EU member state regardless of where the right-holder or entitled persons have their registered office (whether in the EU or outside). Furthermore, the CJ expressly declared that transit may have a direct effect on the internal market because of a risk that counterfeit goods placed under the external transit procedure may be fraudulently brought on to the Community market.

The next Rolex case, ${ }^{3}$ in which Regulation 3295/94 was interpreted as well, originates also from Austria. Unlike the previous judgment, this one related to

2 C-383/98 The Polo/Lauren Company v PT. Dwidua Langgeng Pratama International Freight Forwarders [2000] ECR I-2519.

3 C-60/02 Criminal Proceedings against X (Rolex) [2004] ECR I-651. 
criminal law. The CJ was supposed to answer the question whether Article $2^{4}$ and $11^{5}$ of that Regulation applied to goods in transit. Several persons attempted to transport nineteen counterfeited watches bearing Rolex trademark from Italy to Poland through Austria. Other goods bearing trademarks of La Chemise Lacoste and Guccio Gucci were imported from China and destined for Slovakia. The trademark owners considered such behavior a criminal offence and sought judicial investigation against those persons. But it was questionable whether under Austrian criminal law, transit of goods constituted a crime. The Court ruled that Articles 2 and 11 of the Regulation 3295/94 were applicable to goods in transit temporarily detained in a Member State. In paragraph 58 of the judgment in, it explained that even if the national law did not prohibit and penalize mere transit of counterfeited goods through a territory of the EU, it would be in contradiction with the requirements pursuant to Article 2 and 11 of Regulation 3295/94, and therefore, these provisions were not applicable. In that context, it reminded a duty of national courts to interpret their law in compliance with EU law and if possible, they should apply civil-law remedies to such goods for the purpose of ensuring protection of intellectual property rights against activities prohibited by Article 2 of Regulation 3295/94. ${ }^{6}$

However, in its later judgments, the CJ has deviated from its previous caselaw and has decided that transit of goods throughout EU (from EU to nonmember country or only among Member States) does not infringe a trademark or design right. In paragraph 27 of the Rioglass and Transremar case, ${ }^{7}$ where products originating in Spain destined for Poland went through France, the CJ ruled that transit, which consists in transporting goods lawfully manufactured in a Member State to a non-member country by passing through one or more Member States, does not involve any marketing of the goods in question and is therefore not liable to infringe the specific subject-matter of the trade mark. It concluded that detention of such goods made by customs authorities under the law of a Member State cannot be justified on the ground of protection of industrial and commercial property within the meaning of Article 30 TEC (now Article 36 TFEU).

4 Article 2 of Regulation 3295/94 reads as follows: "The entry into the Community, release for free circulation, export, re-export, placing under a suspensive procedure or placing in a free zone or free warehouse of goods found to be goods referred to in Article 1(2)(a) on completion of the procedure provided for in Article 6 shall be prohibited."

5 This Article requires Member States to introduce penalties for infringements of the prohibition set forth in Article 2 of the Regulation.

6 Paragraphs 59-63 of Rolex case.

7 C-115/02 Administration des douanes et droits indirects $v$ Rioglass and Transremar [2003] ECR I12705

(c) Palacký University Olomouc, Czech Republic, 2014. ISSN 1213-8770 (print), ISSN: 2464-6601 (online). 
Another case (Class International) ${ }^{8}$ deals with interpretation of several provisions of the Trademark Directive ${ }^{9}$ and Community Trademark Regulation ${ }^{10}$ concerning the rights of trademark proprietor. ${ }^{11}$ The CJ clarified in paragraph 50 of the judgment that within the meaning of Trademark Directive and Community Trademark Regulation, a trademark owner cannot oppose the mere entry into the Community, under the external transit procedure or the customs warehousing procedure (a suspensive procedure), ${ }^{12}$ of original goods bearing that mark which have not already been put on the market in the EU previously by that proprietor or with his consent. In that context, it held in the identical paragraph of the judgment that the trademark owner cannot make the placing of goods in transit conditional on the existence, at the time of the introduction of those goods into the $\mathrm{EU}$, of a final destination already specified in a third country, possibly under the purchase contract. The CJ explained that according to Article 37(2) of the old Customs Code, ${ }^{13}$ non-Community (EU) goods subject to the suspensive procedure remain under customs supervision until, in particular, their customs status is changed to EU goods. Goods originating in third countries and placed under the external transit procedure generally pass through one or more Member States after that to be dispatched to a third country. On the other hand, non-EU goods placed under the customs warehousing procedure are generally stored in EU customs territory while awaiting a final destination, which is not necessarily known at the time of storage.

Under the same legislation, a trade mark owner may only oppose the offering or the sale of goods in transit when it necessarily entails the putting of those goods on the EU market. ${ }^{14}$ With regard to the burden of proof, the ECJ ruled

8 C-405/03 Class International $v$ Colgate-Palmolive and Others [2005] ECR I-8735.

9 First Council Directive 89/104/EEC of 21 December 1988 to approximate the laws of the Member States relating to trade marks, now Directive 2008/95/EC of the European Parliament and of the Council of 22 October 2008 to approximate the laws of the Member States relating to trade marks (Codified version)

10 Council Regulation (EC) No 40/94 of 20 December 1993 on the Community trade mark, now Council Regulation (EC) No. 207/2009 of 26 February 2009 on the Community trade mark (codified version

11 Namely Article 5(1) and (3)(c) of Trademark Directive and Article 9(1) and (2)(c) of Community trademark Regulation.

12 The list of suspensive procedures was contained in Article 84 of the Council Regulation (EEC) No 2913/92 of 12 October 1992 establishing the Community Customs Code; namely: external transit, customs warehousing, inward processing in the form of a system of suspension, processing under customs control or temporary importation. This Customs Code was repealed by Regulation (EC) No 450/2008 of the European Parliament and of the Council of 23 April 2008 laying down the Community Customs Code (Modernised Customs Code). In its Article 135, this Modernised Customs Code does not call those procedures suspensive but special procedures instead. They cover transit (external and internal), storage (temporary storage, Customs warehousing, and free zones), specific use (temporary admission and end-use) and processing (inward and outward processing)).

13 Article 91(1) of the Modernised Customs Code.

14 Paragraph 61 of Class International judgment. 
that it is up to the trademark owner to prove release of the non-EU goods for free circulation or an offering or sale of the goods, which necessarily entails their being put on the EU market. ${ }^{15}$

In the Montex case, the CJ, while interpreting Article 5 (1) and (3) of the Trademark Directive, delt with intra-Community transit. In that case, Montex (the defendant) imported jeans from Poland to Ireland, where Diesel's trademark was not protected, through Germany. The goods in a status of external transit were detained by the German customs authority. Diesel alleged that this transit constitutes its trademark infringement because the goods may might be marketed in the transit Member State. The CJ rejected that argument. It held in accordance with its finding in paragraph 61 of Class International case that the trade mark owner can only act against goods in transit when they are subject to an act of a third party, which necessarily entails their being put on the market in the Member State of transit. It means that mere theoretical risk that the goods could be marketed fraudulently in a transit Member State instead of in the country of import, is not sufficient to conclude that there is a trademark infringement.

Similarly, what has been mentioned above with respect to transit of trademarked goods, applies to design rights. ${ }^{16}$ The Cj's judgment in Commission $v$ France dealt with intra-EU transit. ${ }^{17}$ In this particular case, spare parts for cars were lawfully manufactured in Spain and destined for the Italian market without infringement of intellectual property rights there. These goods were detained by the French custom authorities because they infringed registered design rights in France. In paragraph 43 of the judgment in question, the CJ held: "Intra-Community transit consists in the transportation of goods from one Member State to another across the territory of one or more Member States and involves no use of the appearance of the protected design. ... Intra-Community transit does not therefore form part of the specific subject-matter of the right of industrial and commercial property in designs." Therefore, such a detention causing restriction of free movement of goods is not justified on grounds of the protection of industrial and commercial property under Article 30 TEC (Article 36 TFEU).

Conclusions made by the CJ with respect to trademarks were applied by national courts in some Member States also to other intellectual property rights, especially patent rights.

15 Paragraph 75 of Class International judgment.

16 C23/99 Commission v France [2000] ECR I7653

17 I.e., goods coming from one EU Member State to another through a different Member State. 


\section{Rejection of Manufacturing Fiction Theory by the Court of Justice in the Philips and Nokia Cases}

Prior to the judgment in these cases, ${ }^{18}$ a so-called manufacturing fiction theory was applied by some Member State courts (especially Dutch courts). This theory stemmed from Article 6(2)(b) of Regulation No 3295/94 and subsequently from the eight recital of Regulation No 1383/2003. ${ }^{19}$ According to this theory, goods suspended or detained by customs within the EU were considered to be manufactured in the Member State where the custom action took place. Thus, the determination whether or not the goods infringed the intellectual property rights was made on the basis of the law of the Member State in which the custom action occurred. Therefore, the case-law referred to above regarding transit through the EU played no role. But this doctrine clearly ignored the principle of territoriality of intellectual property rights, which is the essential feature of those rights. In the Philips and Nokia judgments, the Court of Justice rejected this manufacturing fiction theory.

The Philips case related to the entry into the EU customs territory of electric shavers infringing the Philip's design and copyrights, and the Nokia case involved to mobile phones and accessories breaching Nokia's trademark rights. All the goods were coming from China. Whereas, Regulation No 2395/94 applies in the first case, Regulation No 1383/2003 is applicable in the second one.

In the Philips case, the Belgian custom authorities suspended the release of the shavers, suspected of infringing upon Philip's copyrights and rights to registered design coming from China and subsequently detained them. The country of destination of those goods was not disclosed. Philips filed a law suit seeking, based on the manufacturing fiction, a ruling that its intellectual property rights were infringed and an order to destroy the goods. The defendant argued that if no proof that the goods were intended to be sold within the EU was presented, the goods could not be detained and classified as infringing an intellectual property right.

In the Nokia case, the UK customs authority released the mobile phones originating from China because they were not directed to the EU but to Colombia and therefore, did not consider such goods counterfeit goods within the meaning of Article 2(1)(a)(i) of Regulation No. 1383/2003. Nokia filed an action against this decision not to seize the consignment.

18 Joined cases C-446/09 and C-495/09 Koninklijke Philips Electronics v Lucheng Meijing Industrial Company and others and Nokia v Her Majesty's Commissioners of Revenue and Customs [2011].

19 "8. Proceedings initiated to determine whether an intellectual property right has been infringed under national law will be conducted with reference to the criteria used to establish whether goods produced in that Member State infringe intellectual property rights." 
The CJ had to solve the question whether goods placed under a suspensive procedure (i.e. the goods coming from a non-member State which are imitations of goods protected in the EU by a trademark right or copies of goods protected there by copyright, a related right or a design) could be classified as 'counterfeit goods' or 'pirated goods' within the meaning of Regulation No 3295/94 and Regulation No. 1383/2003 only on the basis of the fact that they were brought into the customs territory of the EU, without being released for free circulation there.

The CJ examined the temporary detention of the goods placed under a suspensive customs procedure first (Nokia case). According to the judgment in question, the goods in transit directed outside the EU cannot be deemed to infringe intellectual property rights within the meaning of the regulations. But with reference to the General Advocate's opinion, the CJ held that release of the goods may be suspended or detained within the meaning of Article 6(1) of Regulation No 2395/94 or Article 9(1) of Regulation 1383/2003 in case of suspicion of intellectual property rights infringement. Custom authorities are entitled to act when there are indications before them that one or more of the operators involved in the manufacture, consignment or distribution of the goods, while not having yet begun to direct the goods towards European Union consumers, are about to do so or are disguising their commercial intention. Such a suspicion may be supported by the fact that the destination of the goods is not declared whereas the suspensive procedure requested requires such a declaration, the lack of precise or reliable information as to the identity or address of the manufacturer or consignor of the goods, a lack of cooperation with the customs authorities or the discovery of documents or correspondence concerning the goods in question suggesting that there is liable to be a diversion of those goods to EU consumers. In all cases, this suspicion must be based on the facts of the given case."

Furthermore, the CJ stated that imitations and copies of the goods coming from one non-EU Member State to another non-Member State may be in accordance with the intellectual property law in those states. The CJ also argued by abolition of restrictions on trade between Member States, which is also supported by the second recital to the regulations in question according to which the objective of the European Union legislature is restricted to preventing goods infringing intellectual property rights from being 'placed on the market' and to adopting measures for that purpose 'without impeding the freedom of legitimate trade. Therefore, it concluded that those goods, unless indications of suspicion mentioned above exist, must be allowed to pass in transit through the EU without detention. However, those goods suspected of infringement of intellectual property rights in destined non-EU country may be removed from international trade based on the cooperation between custom authorities from EU Member States and those authorities of destined country according to Article 69 of the TRIPS Agreement. ${ }^{20}$

20 Article 69 of the TRIPS Agreement reads as follows: „Members agree to cooperate with 
Subsequently, the CJ dealt with the issue of substantive decision following the temporary detention of goods placed under a suspensive customs procedure (Philips case). The $\mathrm{CJ}$ held that unlike the decision on temporary detention according to Article 6(1) of Regulation No 2395/94 or Article 9/1) of Regulation No 1383/2003, the substantive decision under Article 6(2)(b) of Regulation No 2395/94 or Article 10(1) of Regulation No 1383/2003 must be based on proof of infringement of intellectual property rights and not on the basis of mere suspicion. The authority entitled to make a substantive decision cannot classify as goods infringing an intellectual property right if it is not proven that they are intended to be placed on sale within the EU. Sale in the EU is proven, for example, where it turns out that the goods have been sold to a customer in the EU or offered for sale or advertised to consumers in the EU, or where it is apparent from documents or correspondence concerning the goods that their diversion to EU consumers is envisaged.

But the goods may be seized, regardless its destination (even a non-EU Member State), if they pose a risk to the safety and health of consumers.

Thus, that the CJ clearly deviated from its Polo and Rolex judgments and therefore, they are no longer applicable to goods in transit.

From the given judgment, it is also clear that the regulations in question set forth only the legal framework for taking actions by the customs authorities with regard to transit goods suspected of infringing intellectual property rights and contain no legal basis for determining such an infringement. Thus, the customs authorities may detain the goods in transit based on sufficient grounds that these products will be put on the EU market. Subsequently, it is up to the appropriate court to decide, according to national or EU law, whether they infringe intellectual property rights. But under the Philips and Nokia judgment, if the right holder does not prove that they are destined for the EU, they should not be considered counterfeit or pirated goods and therefore, should be released.

\section{Reasons for Speed Adoption of the New Customs Regulation}

During 2008-2009, Dutch Customs, based on the manufacturing fiction, detained shipments of generic drugs manufactured in India and destined for Brazil. The drugs were in transit through the Netherlands where they were protected by patent. This patent was not protected in India and Brazil. However, at least in one case, the generic drugs directing to Republic of Vanuatu were seized

each other with a view to eliminating international trade in goods infringing intellectual property rights. For this purpose, they shall establish and notify contact points in their administrations and be ready to exchange information on trade in infringing goods. They shall, in particular, promote the exchange of information and cooperation between customs authorities with regard to trade in counterfeit trademark goods and pirated copyright goods." 
by German customs authorities based on suspicion of trademark violation. ${ }^{21}$ These drugs were released after four weeks following declaration of the British drug manufacturer GlaxoSmithKline that there was no trademark infringement.

On May 19, 2010, India and Brazil separately filed a request for consultation at the WTO against the EU and the Netherlands alleging breaches of Articles V (Freedom of Transit) and X (Publication and Administration of Trade Regulations) of the GATT 1994 and of various articles of the TRIPS Agreement. ${ }^{22}$ Both countries asserted that the Regulation No 1383/2003 undermined the freedom of transit principle contained in the GATT. In July 2011, India and the EU reached the Understanding, which, inter alia, contains the principles to guide border enforcement of intellectual property in the EU. ${ }^{23}$ India agreed not to request the establishment of a dispute settlement panel at WTO and the EU, among other things, agreed to adopt guidelines for customs authorities, informing them not to seize medicines in transit if there is no evidence that the goods are diverted to the EU market, and to adopt new customs regulation reflecting the principles reached in the Understanding. But India kept the option to continue in the dispute if the EU does not fulfill the principles in question.

The Philips and Nokia cases and consultations within WTO led to expedited preparation of proposal of the new regulation. ${ }^{24}$ The proposal for this new regulation was subject to criticism from various sides. ${ }^{25}$

In 2013, the EU based on that proposal adopted Regulation No 608/2013 $3^{26}$ which repeals Regulation No 1383/2003. This Regulation became effective on January 1, 2014.

21 European Generic Drug Seizures Take Centre Stage at TRIPS Council Meeting | International Centre for Trade and Sustainable Development (June 10, 2009), available at: http:// www.ictsd.org/bridges-news/bridges/news/european-generic-drug-seizures-take-centrestage-at-trips-council-meeting.

22 European Union and a Member State - Seizure of Generic Drugs in Transit, Request for Consultations by India (WT/DS408/1 - May 19, 2010) and European Union and a Member State - Seizure of Generic Drugs in Transit, Request for Consultations by Brazil (WT/ DS409/1 - May 19, 2010).

23 Press release of Ministry of Commerce \& Industry (India) dated July 28, 2011 is available at: http://pib.nic.in/newsite/erelease.aspx?relid=73554.

24 An in-depth analysis of this proposal is presented in article entitled "The European Commission's proposal for a regulation concerning Customs enforcement of IP rights" by Olivier Vrins, Journal of Intellectual Property Law \& Practice, 2011.

25 For example: Baker, Brook K. 2012. Settlement of India/EU WTO Dispute re Seizures of In-Transit Medicines: Why the Proposed EU Border Regulation Isn't Good Enough. PIJIP Research Paper no. 2012-02 American University Washington College of Law, Washington, D.C; available at: http://digitalcommons.wcl.american.edu/cgi/viewcontent.cgi?articl $\mathrm{e}=1026 \&$ context $=$ research.

26 Regulation (EU) No 608/2013 of the European Parliament and of the Council of 12 June 2013 concerning customs enforcement of intellectual property rights and repealing Council Regulation (EC) No 1383/2003. 
Recital 10 makes clear that this Regulation contains only procedural rules for customs authorities which means that this Regulation does not stipulate any criteria for ascertaining the existence of an infringement of an intellectual property right. This principle is reflected in Article 1(6) according to which the Regulation does not affect national or EU law on intellectual property. Therefore, it is obvious that determination whether or not the intellectual property rights are infringed is based solely on the EU or national law regulating these rights. Nevertheless, as it will be pointed out in the next part of this paper, the Commission within its legislative activities proposes to overturn the outcome of Philips and Nokia judgment.

Within the meaning of Recital 15 of this Regulation, custom authorities, when deciding whether or not to suspend or detain the goods, may base their suspicion of infringement on reasonable indications which corresponds to the CJ's judgment in Philips and Nokia cases. Suspected goods may be suspended or detained if there is an indication that they are not destined for the non-Member State, for instance, if the state of importation is not properly indicated in the appropriate documents.

Recital 11 expressly deals with transit of drugs throughout the EU and in that context, it refers to "Declaration on the TRIPS Agreement and Public Health" adopted by the Doha WTO Ministerial Conference on 14 November 2001 (hereinafter "the Doha Declaration") under which the TRIPS Agreement should be interpreted in a manner allowing WTO Members to protect public health and especially to promote access to medicines for all. With regard to drugs in transit, the customs authorities of Member States should, therefore, when assessing a risk of infringement of intellectual property rights, take account of any substantial likelihood of diversion of such medicines onto the market of the EU. Thus, in case of drugs, the evaluation in term of infringement of rights seems to be more stringent (substantial likelihood of diversion on the EU market) than with respect to other goods (reasonable indications).

Even when the recitals do not form the substantial provisions of the Regulation, nevertheless, these provisions should be interpreted within the meaning of the recitals.

Under Recital 21 and underlying Article 22 of that Regulation, the custom authorities of Member States are allowed to share information with authorities from third countries, inter alia, about goods in transit originating in or destined for the territory of third countries.

According to Article 37, the Commission has the reporting duty toward the European Parliament and the Council by December 31, 2016. In its report, it must inform about any relevant incidents regarding drugs in transit across the customs territory of the EU, including an assessment of its potential impact on the EU commitments on access to medicines under the Doha Declaration, 
and the measures taken to address any situation creating adverse effects in that regard.

\section{Overturning of the impact of Philips and Nokia Cases within the Pro- posed Changes in EU Trademark Law}

But the proposal for amendment to the Regulation on Community trade mark, ${ }^{27}$ as a part of the trademark reform within the EU, goes directly against the ruling in the Philips and Nokia cases and against the Understanding between the EU and India. Newly proposed paragraph 5 of Article 9 reads as follows: "The proprietor of a European trade mark shall also be entitled to prevent all third parties from bringing goods, in the context of commercial activity, into the customs territory of the Union without being released for free circulation there, where such goods, including packaging, come from third countries and bear without authorization a trade mark which is identical to the European trade mark registered in respect of such goods, or which cannot be distinguished in its essential aspects from that trade mark." Paragraph 5 of Article 10 of the proposal of the new Trademark directive ${ }^{28}$ is formulated in a similar manner. Trademark owners and trademark associations were in favor of those proposals. ${ }^{29}$

However, on February 25, 2014, the European Parliament during the first reading adopted many amendments to both proposals, including provisions dealing with goods in transit. ${ }^{30}$ It inserted a restrictive clause at the end of the articles in question by making reference to WTO rules, in particular Article V of the GATT on freedom of transit. Furthermore, the European Parliament added into recitals of the proposed legislative texts that the smooth transit of generic medicines, in compliance with the international obligations of the European Union, in particular as reflected in the Doha Declaration may not be touched. The reference to that Declaration is mentioned in the Opinion of the Committee on International Trade of the European Parliament of October 14, 2013. ${ }^{31}$

27 European Commission, Brussels, 27.3.2013, COM(2013) 161 final, 2013/0088 (COD) Proposal for a REGULATION OF THE EUROPEAN PARLIAMENT AND OF THE COUNCIL amending Council Regulation (EC) No 207/2009 on the Community trade mark.

28 European Commission, Brussels, 27.3.2013, COM(2013) 162 final, 2013/0089 (COD) Proposal for a DIRECTIVE OF THE EUROPEAN PARLIAMENT AND OF THE COUNCIL to approximate the laws of the Member States relating to trade marks (Recast).

29 For example, joint letter of various trademark associations of March 7, 2013; available at: http://www.ecta.org/IMG/pdf/joint_letter_goods_in_transit_commissioner_barnier-2.pdf.

30 Amendments to the proposals adopted by the European Parliament on February 25, 2014 are available at: Regulation: http://www.europarl.europa.eu/sides/getDoc. do?type $=$ TAlanguage $=$ ENreference $=$ P7-TA-2014-0118; Directive: http://www.europarl. europa.eu/sides/getDoc.do?type=TAlanguage=ENreference=P7-TA-2014-0119

31 European Parliament, Opinion of the Committee on International Trade of 14.10.2013, 2013/0088(COD) 
Both amended proposals were transmitted to the Council where the issue of goods in transit was highly debated. On July 23, 2014, the Committee of Permanent Representatives (Coreper) agreed on a Council common position on the two legislative proposals in question and mandated the Presidency of the Italian Council to enter into negotiations with the European Parliament with a view to concluding a swift agreement. ${ }^{32}$ Negotiations between the European Parliament, Council and Commission continue at the beginning of 2015.

\section{Conclusion}

In the opinion of the author of this text, formulating the aforementioned provisions of the Community Trade mark Regulation and Directive directly against the ECJ's ruling, as the Commission proposed, would undermine legal certainty and the position of the Court. On one hand, it is understandable that the EU contemplates to discourage transit of goods infringing intellectual property rights through its territory but on the other hand, other aspects should be taken into account, such as, principle of territoriality of intellectual property rights and international obligations of the EU. It is doubtful whether these provisions are in compliance, inter alia, with Article 52 of the TRIPS Agreement according to which the right holder initiating the procedure for the purpose of suspension of counterfeit trademark or pirated copyright goods by the customs authorities must provide adequate evidence that under the laws of the country of importation, there is prima facie an infringement of the right holder's intellectual property right.

Moreover, such attitude is not justifiable especially in cases in which the goods do not infringe intellectual property rights in both country of origin and destination as happened in the case of generic drugs imported from India to Brazil mentioned above. Due to principle of territoriality of intellectual property rights, there is no justification why such goods (not only drugs) should not be allowed to pass through the EU even if they infringe those rights there.

It may be agreed that the problem with transit of drugs relates especially to patent rights but trademark cases may not be excluded. Moreover, as it has been pointed out above, the problem in question does not relate only to drugs but other legitimate goods.

The situation might be different if the goods infringed the rights in country of origin or destination. In such a case, these goods could be deemed infringing the rights and border measures could apply to them. ${ }^{33}$

32 Press release is available at: http://www.consilium.europa.eu/uedocs/cms_data/docs/ pressdata/en/intm/144127.pdf.

33 The author of article mentioned in footnote 23 is in favour of that solution. 